\title{
ЕТАПИ ФОРМУВАННЯ ЛОГІЧНОЇ КУЛЬТУРИ МАЙБУТНІХ УЧИТЕЛІВ ІНОЗЕМНОЇ МОВИ
}

Лопатич Р. В. Етапи формування логічної культури майбутніх учителів іноземної мови.

У статті визначено етапи формування логічної культури майбутніх учителів іноземної мови: мотиваційний, технологічний та рефлексивно-аналітичний. 3'ясовано методи та заходи, які підвищують рівень сформованості логічної культури майбутніх учителів іноземної мови.

Ключові слова: логічна культура, мотиваційний етап, технологічний етап, рефлексивно-аналітичний етап.

Лопатич Р. В. Этапы формирования логической культуры будущих учителей иностранного языка.

В статье определены этапы формирования логической культуры будущих учителей иностранного языка: мотивационный, технологический и рефлексивно-аналитический. Выяснено, какие методы повышают уровень сформированности логической культуры будущих учителей иностранного языка.

Ключевые слова: логическая культура, мотивационный этап, технологический этап, рефлексивно-аналитический этап.

Lopatych R. W. Stages of logical culture formation of future teachers in foreign languages.

The article is devoted to the problem of logical culture formation of future teachers in foreign languages. The stages of forming logical culture of future teachers in foreign languages are defined: motivational, technological, reflexive and analytical. The methods for improvement of logical culture level of teachers in foreign languages are considered.

Key words: logical culture, motivational stage, technological stage, reflexive and analytical stage.

Результати багатьох досліджень свідчать, що під час вивчення програмних дисциплін студенти демонструють неспроможність вільно й послідовно висловлювати власну думку, логічно викладати зміст прочитаних текстів, що вказує на низький рівень сформованості їхньої логічної культури. Оскільки вчитель іноземної мови має безпосереднє відношення до розвитку логічного мислення учнів, формування у них навичок логічного викладу думок та зв'язного мовлення, він повинен володіти логічною культурою. Тому слід приділяти проблемі формування логічної культури майбутніх учителів іноземної мови належну увагу. Зважаючи на це, важливо ще під час навчання у вищій школі сформувати в майбутніх спеціалістів високий рівень логічної культури, що є одним із складників його фаховості.

За останні роки проблемі формування логічної культури було присвячено багато публікацій. У філософському вимірі це питання розв'язували В. Брюшинкін, А. Гетьманова, Є. Іванов, В. Журавльов, С. Марценюк, В. Свінцов. Суттєвим науковим доробком у визначенні ролі логічної культури в розвитку мовлення стали надбання мовознавців Н. Бабич, В. Колшанського, Л. Паламар. Досліджувались різні аспекти цього феномену в педагогіці. Так, О. Лазаревич приділяє увагу формуванню логічної культури молодших 
школярів, в той час як Г. Лаврешина розглядає формування логічної культури старшокласників. Значно доповнюють дослідження цього питання О. Тихомирова та О. Халабузар, які вивчають проблеми формування логічної культури у студентів та спеціалістів. Російські педагоги (О. Баринова, С. Баширова, О. Яковлева) вивчають проблеми формування логічної культури у студентів 3 метою підвищення рівня професійної підготовки. Окремі аспекти засвоєння знань шляхом міркувань відображено в дослідженнях представників німецької школи іншомовної освіти П. Біммеля (P. Bimmel), Й. Гербеса (J. Gerbes), У. Гревера (U. Grewer), М.Крюгера (M. Krüger), Г. Нойнера (G. Neuner), M. Райманн (M. Reimann). Проте аналіз наукової літератури з теми надає підстави свідчити, що, незважаючи на певну увагу до означеної проблеми та наявність результатів дослідження окремих iï аспектів, недостатньо вивчені етапи формування логічної культури майбутніх учителів іноземної мови.

Розв'язанню цього питання присвячується стаття, метою якої є дослідити процес формування логічної культури майбутніх учителів іноземної мови. У зв'язку з цим ми ставимо перед собою завдання визначити етапи формувння логічної культури майбутніх учителів іноземної мови.

У процесі наукового пошуку з'ясовано, що логічна культура розглядається у працях науковців як: елемент загальної культури [1]; складне особистісне новоутворення, що включає вміння аналізувати, критично мислити [2; 3; 4], а також такі якості, як точність, чіткість, послідовність мислення та вміння не допускати у своїх міркуваннях суперечності, доводити, обгрунтовувати й дискутувати [5]. Виходячи 3 того, що логічна культура $\epsilon$ складним новоутворенням, було визначено етапи формування логічної культури: мотиваційний, технологічний та рефлексивно-аналітичний.

Мотиваційний етап забезпечує теоретико-методичну підготовку викладачів вищих навчальних закладів щодо формування логічної культури студентів; об'єктивне оцінювання студентами власного рівня сформованості логічної культури, з'ясування ними шляхів подальшого ії розвитку; ознайомлення майбутніх учителів іноземної мови із сутністю форм, засобів та методів навчально-пізнавальної діяльності, які сприяють ефективному формуванню логічної культури; стимулювання їх до активної участі в навчальному процесі. На цьому етапі роботу спрямовано на розвиток позитивної мотивації студентів, стимулювання їх до формування логічної культури, усвідомлення важливості їі набуття в подальшій професійній діяльності. Ефективність реалізації змісту окресленого етапу досягалася за рахунок проведення науково-методичного семінару для викладачів «Формування логічної культури на заняттях з іноземної мови», метою якого було розкриття сутності логічної культури, акцентування уваги слухачів на їі значущості у процесі оволодіння майбутніми вчителями іноземної мови навчальної компетентності у процесі фахової підготовки, підвищення рівня інформованості викладачів щодо засобів формування логічної культури студентів, ознайомлення 3 методикою проведення нетрадиційних занять 3 використанням інтерактивних методів, творчих завдань мисленнєвого характеру. Проведена робота сприяла формуванню й розвитку позитивної мотивації.

Технологічний етап мав на меті створення мотиваційно-професійного середовища задля формування компонентів логічної культури. Оскільки майбутній учитель іноземної мови повинен володіти системою знань, умінь і навичок, необхідних для виконання професійних обов'язків, сукупністю ціннісних настанов, особистісних якостей, що забезпечують його успішну діяльність, тому необхідно створити відповідні умови повсякденної професійної діяльності, які спонукають студентів до самовдосконалення і тим 
самим підвищують їхню готовність до навчання. На цьому етапі було визначено основні напрями формування логічної культури майбутніх учителів іноземної мови, що передбачало формування у них логічних, комунікативних, рефлексивних умінь і навичок мислення. Для цього був оновлений зміст навчальної дисципліни «Практичний курс німецької мови». Розгляд додаткових питань у контексті означеного курсу дозволив урізноманітнити основний навчальний матеріал, зосередити увагу студентів на важливості формування логічної культури, підвищити рівень вмотивованості та інтересу учасників у роботі над темами занять. На цьому етапі поєднувалися традиційні і нетрадиційні форми та методи фахової підготовки майбутніх учителів іноземної мови (комплекс тренувальних вправ, інтерактивні, проектні методи, проблемні і ситуативні завдання, моделювання професійно спрямованих завдань тощо). Це надало можливість не тільки урізноманітнити форми та методи формування логічної культури, але й удосконалити у студентів знання законів логічного мислення, засобів формування логічної культури, логічні уміння і навички та забезпечити формування логічної культури в майбутніх учителів іноземної мови.

Рефлексивно-аналітичний етап формування логічної культури передбачав формування стійкої рефлексивної позиції у студентів, самостійності під час пізнання нового матеріалу. Необхідною умовою реалізації на цьому етапі є залучення майбутніх учителів до аналітикооцінювальної діяльності шляхом упровадження проблемного навчання, створення ситуацій, які потребують від студентів застосування логічних умінь і навичок мислення. Ефективність реалізації змісту цього етапу досягалася за рахунок проведення під час практичних занять 3 німецької мови дискусій, бесід, аналізу виконання навчальних завдань, ведення щоденників власних досягнень тощо. У процесі спільної діяльності студенти набували й відпрацьовували вміння аналізувати, аргументувати та доводити власну думку іноземною мовою.

Отже, проведена робота забезпечила підвищення рівня сформованості в майбутніх учителів іноземної мови логічної культури. Реалізація таких заходів, як: забезпечення цілеспрямованого навчання прийомів мисленнєвої діяльності, використання сучасних активних форм та методів навчання, проведення науково-методичного семінару для викладачів «Формування логічної культури на заняттях 3 іноземної мови», застосування авторського комплексу тренувальних вправ, інтерактивних, проектних та дискусійних технологій, розроблених навчальних завдань мисленнєво-мовленнєвого характеру, активізують логічне мислення та логічне мовлення студентів і значно впливають на розвиток логічної культури майбутніх учителів іноземної мови. Проведене дослідження не вичерпує всіх аспектів формування логічної культури майбутніх учителів іноземної мови у процесі фахової підготовки. Подальшого наукового розроблення потребують проблеми педагогічного супроводу фахової підготовки, укладання методичних посібників і підготовка дидактичних матеріалів.

\section{Література}

1. Баринова О. Ю. Дидактическая система формирования логической культуры студентов средствами иностранного языка / О. Ю. Баринова // Образование и саморазвитие. Казань : Центр инновационных технологий. - 2008. - № 4 (10). - С. 87-92. 2. Лаврешина Г. Ю. Формування логічної культури у старшокласників : автореф. дис. на здобуття наук. ступеню канд. пед. наук: спец. 13.00.09 «Теорія та методика навчання»/ Г. Ю. Лаврешина. - Кривий Ріг, 2001. - 20 с. 3. Тихомирова О. В. Формирование логической культуры студентов юридического факультета [Электронный ресурс] / О. В. Тихомирова. Режим доступа : http://www.bytic.ru/cue99M/cqi1jpy9qh.html. 4. Фаткуллова Л. Н. Формирование культуры логического мышления будущих учителей в условиях 
интегрального образовательного пространства : дис.. ... канд. пед. наук : 13.00.01 / Лейсан Наиловна Фаткуллова. - Казань, 2010. - 245 с. 5. Халабузар О. А. Формування культури логічного мислення майбутнього вчителя у процесі фахової підготовки : дис. ... канд. пед. наук : 13.00.04 / Оксана Анатоліївна Халабузар. - Бердянськ, 2008. - 319 с.

Тетяна Плачинда

\section{ПРОФЕСІЙНА РЕФЛЕКСІЯ ЯК УМОВА СТАНОВЛЕННЯ МАЙБУТНЬОГО ФАХІВЦЯ}

Плачинда Т. С. Професійна рефлексія як умова становлення майбутнього фахівця.

Аналізуються поняття «рефлексія», «професійна рефлексія». Вивчаються думки науковців щодо ролі рефлексивного компонента в навчально-виховному процесі майбутніх фахівців. Подано авторське тлумачення поняття «рефлексія». Наведено дані тестування курсантів льотних навчальних закладів щодо рівнів сформованості професійної рефлексії. Говориться про те, що за умови формування у студентів навичок рефлексії, майбутній фахівець буде висококваліфікованим та конкурентоспроможним на ринку праці як в Україні, так і міжнародному співтоваристві.

Ключові слова: майбутній фахівець, рефлексія, професійна рефлексія, самоорганізація, навчально-професійна діяльність.

Плачинда Т. С. Профессиональная рефлексия как условие становления будущего специалиста.

Анализируются понятия «рефлексия», «профессиональная рефлексия». Изучаются позиции ученых о роли рефлексивного компонента в учебно-воспитательном процессе будущих специалистов. Представлено авторское толкование понятия «рефлексия». Приведены данные тестирования курсантов летных учебных заведений относительно уровней сформированности профессиональной рефлексии. Говорится о том, что в условиях формирования у студентов навыков рефлексии, будущий специалист будет высококвалифицированным и конкурентоспособным на рынке труда как в Украине, так и в международном сообществе.

Ключевые слова: будущий специалист, рефлексия, профессиональная рефлексия, самоорганизация, учебно-профессиональная деятельность.

Plachynda T. S. Professional reflection as a condition of future specialist development.

The defenitions of «reflection» and «professional reflection» are analyzed. Scientists' opinions about the role of the reflexive component in the educational process of future specialists are studied. The author's interpretation of the term «reflection» is given as well as the data of testing the flight cadets concerning the levels of professional reflection development. It is also stated that in the conditions of students' reflection skills formation, the future specialist will be highly skilled and competitive on labour market both in Ukraine and in the international community.

Key words: future specialist, reflection, professional reflection, self-organization, training and professional activity.

Глобалізація економіки, формування інформаційного суспільства та інтеграція 